I. - MÉTHODOLOGIE GÉNÉRALE

\title{
DOSAGE DES OSES, DES DI- ET TRIHOLOSIDES PAR Chromatographie eN Phase gazeUse
}

\author{
J.-P. JOUANY \\ Station de Recherches sur l'Elevage des Ruminants \\ Centre de Recherches de Clermont-Ferrand, I. N. R. A., \\ 63 - Saint-Genès-Champanelle
}

La méthode que nous proposons a été mise au point pour séparer et doser simultanément les pentoses, les hexoses, les di- et triholosides à l'état libre, ou obtenus après hydrolyse, dans les contenus de rumen.

L'échantillon à analyser est préalablement lyophilisé ; il subit une éthérification qui transforme les fonctions - hydroxyles des glucides en - éthers $O$ triméthylsilylés qui sont volatils.

$$
\searrow \mathrm{C}-\mathrm{OH}-\ldots \ldots-\ldots \mathrm{C}-\mathrm{O}-\mathrm{Si}\left(\mathrm{CH}_{\mathrm{a}}\right)_{3}
$$

Ceux-ci sont séparés par chromatographie en phase gazeuse. L'utilisation d'un standard interne (Inositol) permet d'évaluer quantitativement les différents pics obtenus.

Les modifications que nous avons apportées aux méthodes classiques de chromatographie en phase gazeuse des glucides sont les suivantes :

a) Au cours de la réaction de silylation, les glucides sont dissous non pas dans la pyridine (SwEELEY et al., 1963) mais dans le diméthylformamide (ELLIS, 1969) qui permet d'obtenir des résultats quantitatifs plus précis, surtout lorsque l'on veut séparer les pentoses.

b) Les quantités des réactifs de silylation (hexaméthyldisilazane et triméthylchlorosilane) ont été déterminées de façon à doser quantitativement les glucides même si l'échantillon n'est pas parfaitement anhydre.

c) La phase stationnaire utilisée est une résine silicone diméthyl non polaire $\left(\mathrm{OV}_{1}\right)$ dont la température limite d'utilisation est élevée $\left(35^{\circ} \mathrm{C}\right)$, ce qui permet l'élution des triholosides à $320^{\circ} \mathrm{C}$.

Cette méthode permet une séparation complète de la plupart des glucides simples que l'on rencontre généralement dans les milieux biologiques. Cependant, certains glucides sont mal séparés (arabinose-rhamnose et fructose-mannose) et il sera sans doute nécessaire, pour résoudre ces problèmes, d'utiliser des colonnes capillaires.

\section{SUMMARY}

\section{QUANTITATIVE GAS CHROMATOGRAPHY OF MIXTURES OF OSES, DI - AND TRIHOLOSIDES}

The method proposed in the present paper has been elaborated with the view of a simultaneous separation and quantitative determination of the free pentoses, hexoses, di- and triholosides, or those obtained after hydrolysis, in the rumen coptents. 
The sample to be analysed is previously lyophilized; it undergoes an etherification which transforms the hydroxyle functions of carbohydrates into volatile $O$ trimethylsilylated ethers.

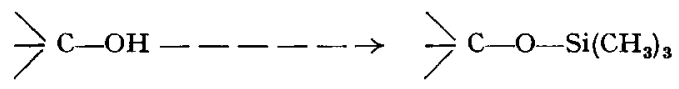

which were separated by gas chromatography. The utilization of an internal standard (Inositol) allowed a quantitative evaluation of the different peaks.

The classic methods of gas chromatography of carbohydrates are changed as follows :

a) During the trimethyl silylation, the carbohydrates were not dissolved in pyridine (SwEELEY et al., 1963), but in dimethylformamide (ElLIS, 1969) which resulted in formation of hexamethyldisiloxane giving more accurate quantitative results, in particular when separating pentoses.

b) The amounts of silylation reagents (hexamethyldisilazane and trimethylchlorosilane) were determined so as to obtain a quantitative dosage of the carbohydrates even if the sample was not perfectly anhydrous.

c) The stationary phase used was a non polar dimethyl silicone resin $\left(\mathrm{OV}_{1}\right)$ with a high temperature limit $\left(35^{\circ} \mathrm{C}\right)$ allowing elution of the triholosides at $320^{\circ} \mathrm{C}$.

By means of this method it is possible to realize a complete separation of most of the simple carbohydrates generally present in biological media. However, some carbohydrates are not well separated (arabinose-rhamnose, and fructose-mannose) and, to resolve these problems, it will probably be necessary to use open tubular columns.

\title{
RÉFÉRENCES BIBLIOGRAPHIQUES
}

ELLIS W. C., I969. Solvents for the formation and quantitative chromatography of trimethylsilyl derivatives of monosaccharides. J. Chromatogr., 41, 325-334.

Sweeley C. C., Benteey R., Makita M., Wells W. W., ig63. Gas-liquid chromatography of trimethysilyl derivatives of sugars and related substances. J. Am. Chem. Soc., 85, 2497-2507.

\section{PRÉLÈVEMENT AUTOMATIQUE DE CONTENUS INTESTINAUX CHEZ LE VEAU ET LE MOUTON}

\author{
P. THIVEND et C. PONCET \\ Station de Recherches sur l'Élevage des Ruminants, \\ Centre de Recherches de Clermont-Ferrand, I. N. R. A., \\ 63 - Saint-Genès-Champanelle
}

Nous avons mis au point un appareil qui permet de prélever automatiquement les contenus digestifs chez des veaux ou des moutons porteurs de double-canules intestinales (AsH, I962). I1 se compose de trois éléments :

- le collecteur qui recueille le contenu digestif par fraction dont le volume est réglable (de 20 à $80 \mathrm{ml}$ ) ; 